Ankara Üniversitesi

SBF Dergisi,

Cilt 73, No. 3, 2018, s. 787 - 809

\title{
ULUSAL VE ULUSÖTESI TOPLUMSAL HAREKETLER VE YENI BILGI ve ILETiŞiM TEKNOLOJILERI
}

\author{
Uzman Hillal Atilla \\ Çukurova Üniversitesi \\ İktisadi ve İdari Bilimler Fakültesi \\ ORCID: 0000-0002-5781-6495
}

\author{
Dr. Öğr. Üye. Marella Bodur Ün \\ Çukurova Üniversitesi \\ İktisadi ve İdari Bilimler Fakültesi \\ ORCID: 0000-0001-6828-3690
}

\section{Öz}

Internet tabanlı iletişim teknolojilerinin yerel, ulusal ve ulusötesi toplumsal hareketler tarafindan giderek daha fazla kullanılır hale gelmesiyle ve buna bağlı olarak toplumsal hareketlerin iletişim, mobilizasyon ve protesto dinamiklerinde meydana gelen değişimlerle beraber, yeni Bilgi ve İletişim Teknolojileri (BIT) konusu toplumsal hareket çalışmalarının gündeminde önemli bir yer edinmeye başlamıştır. Küresel Adalet Hareketi, Arap Baharı ve Wall Street'i İşgal Et gibi toplumsal hareketler, geniş kitlelere ulaşmak, katılımcı ve destekçi sayısını arttırmak ve hedeflerine ulaşabilmek için yeni iletişim teknolojilerinden ağırlıklı olarak faydalanmıştır. Bu makalede, toplumsal hareket çalışmaları alanında geliştirilen kavram ve kuramlara dayanarak, yeni BİT ve toplumsal hareketler arasındaki ilişki incelenecektir. Bu bağlamda, yeni BíT'in kullanım amaçları, yarattı̆̆ı firsatlar, avantajları ve dezavantajları farklı toplumsal hareketlerden örnekler verilerek analiz edilecektir. Çalışmamız, yeni BíT’in zemin hazırladığı toplumsal değişimlerle birlikte, toplumsal hareketlerin oluşum, iletişim, mobilizasyon ve protesto dinamiklerinde de değişimler gerçekleştiğini iddia etmekte ve yeni BİT kullanımının toplumsal hareketlere etkilerini inceleyerek toplumsal hareketler literatürüne katkı yapmayı amaçlamaktadır.

Anahtar Sözcükler: Toplumsal Hareketler, Bilgi ve İletișim Teknolojileri, Sosyal Ağlar, Yeni Medya, Çerçeveleme

National and Transnational Social Movements and New Information and Communication Technologies

\begin{abstract}
With the increasing usage of Internet-based communication technologies by local, national and transnational social movements and the resultant changes in the communication, mobilization and protest dynamics of these movements, new Information and Communication Technologies (ICTs) have become the focus of much academic research in social movement studies. In order to publicize their demands, attract potential participants and realize their aims, social movements such as the Global Justice Movement, the Arab Spring, and the Occupy Wall Street have employed new communications technologies. Drawing on the conceptual and theoretical tools developed by social movement researchers, this study focuses on the relationship between new ICTs and social movements in terms of the opportunities they open up and their advantages and disadvantages, referring to different social movements from around the world. This study aims to make a contribution to the existing literature by uncovering the changing dynamics of mobilization, communication and protest of social movements as a result of the usage of new ICTs.
\end{abstract}

Keywords: Social Movements, Information and Communication Technologies (ICTs), Social Networks, New Media, Framing

* Makale geliş tarihi: 01.10.2017

Makale kabul tarihi: 08.01.2018 


\section{Ulusal ve Ulusötesi Toplumsal Hareketler ve Yeni Bilgi ve İletişim Teknolojileri' ${ }^{1}$}

\section{Giriş}

Bilgi ve İletişim Teknolojileri (BİT) alanında meydana gelen gelişmeler sonucunda yaşanan toplumsal değişimler, toplumsal hareketler için de yeni bir dönemin başlamasına neden olmuştur. Zapatista Hareketi, Küresel Adalet Hareketi, Arap Baharı, Wall Street'i İşgal Et ve Gezi Parkı gibi örneklerde görüldüğü üzere Internet tabanlı yeni iletişim platformlarının yaygın olarak kullanılmaya başlanması, ulusal ve ulusötesi toplumsal hareketlerin etki alanında ve erişilebilir kaynaklarında büyük ölçüde genişleme meydana getirmiştir. Yeni iletişim teknolojileri, özellikle bir toplumsal hareketin mesajının yayılması ve potansiyel destekçilerin katılım kararı üzerinde önemli etkiye sahip olan sosyal ağlar ve medya temsili alanlarında önemli avantajlar sağlamaktadır. Çevrimiçi tartışma forumları, bloglar ve sosyal medya siteleri gibi zeminlerde gerçekleştirilen bilgi ve görüş alışverişleri, alternatif kamusal alanların oluşumuna imkân vermektedir. Potansiyel destekçiler, değişik siyasal düşüncelerin dile getirildiği bu alanlar sayesinde çeşitli toplumsal hareketlerin varllğından, söylemlerinden ve aktivitelerinden haberdar olarak bunlara katılım firsatı elde etmektedir. Ayrıca, bu alternatif kamusal alanların toplumsal hareketler tarafından mesajlarını geniş kitlelere duyurmak amacıyla kullanılıyor olmasının, bu hareketlerin geleneksel medyaya olan bağımlılığını azalttığı da gözlemlenmektedir. Ancak bu avantajların yanı sıra, Internet tabanlı iletişim teknolojilerinin gelişimi ve yaygınlaşmasıyla ortaya çıkan, "slacktivism", "hacktivism", bilgi kirliliği, yeni kontrol mekanizmaları, hükümetler tarafından kişisel bilgilere erişim ve yeni BİT'in beraberinde getirdiği tecrübesizlik gibi dezavantajlar da bulunmaktadır.

$1 \mathrm{Bu}$ araştırma, Çukurova Üniversitesi Bilimsel Araştırma Projeleri Birimi tarafından desteklenmiştir. Makale, Dr. Öğr. Üyesi Marella Bodur Ün'ün danışmanlığında Hilal Atilla tarafindan yazılan "Yeni Toplumsal Hareketler ve Yeni Bilgi ve İletişim Teknolojileri: Türkiye'deki Nükleer Karşıtı Platform Örneği" başlıklı Yüksek Lisans tezinden revize edilerek hazırlanmıştır. 
$\mathrm{Bu}$ çalışma, yeni Bilgi ve İletişim Teknolojileri'nin (Information and Communication Technologies-ICTs) zemin hazırladığı toplumsal değişimlerle birlikte toplumsal hareketlerin oluşum, gelişim, mobilizasyon ve protesto dinamiklerinde değişimler gerçekleştiğini öne sürerek, bu değişimlerin toplumsal hareketler için önemli bir söylemsel firsat yapısı ve kaynak oluşturduklarını iddia etmektedir. Araştırma kapsamında yeni medya öğelerinin toplumsal hareketler için yarattığı firsatlar ve beraberinde getirdiği avantaj ve dezavantajlar incelenerek toplumsal hareketler literatürüne katk1 yapılması amaçlanmaktadır. Çalışmanın birinci bölümünde toplumsal hareket çalışmaları alanına hâkim olan Kaynak Mobilizasyonu ve Yeni Toplumsal Hareket teorilerinin kolektif eylem analizi için sundukları katkılar belirlenerek kuramsal bir çerçeve çizilecektir. İkinci bölümde, araştırmanın odak noktalarından olan yeni Bilgi ve İletişim Teknolojileri (BİT) kavramına ve yeni BİT'in neden olduğu yapısal değişiklikler sonucu ortaya çıkan "ağ toplumu" kavramına dair görüşler ele alınacaktır. Üçüncü bölümde ise yeni BİT'in toplumsal hareketler üzerindeki etkileri, iletişim, mobilizasyon, çerçeveleme, sosyal ağlar ve ulusötesi örgütlenme süreçleri açısından incelenecektir.

\section{Toplumsal Hareket Çalışmaları}

Toplumsal hareket kavramına dair literatürde kabul edilen ortak bir tanım bulunmamaktadır. Farklı yaklaşımlar, toplumsal hareketleri, kendi analiz çerçevesine dâhil olan ögeler kapsamında tanımlamakta ve toplumsal hareket çalışmalarının hangi araştırma sorularını sorması ve hangi noktalara odaklanması gerektiğine dair farklı değerlendirmeler sunmaktadır. Kaynak Mobilizasyonu Teorisi'ni geliştiren John McCarthy ve Mayer Zald (1977: 1217-18) alanda artık klasikleşmiş olan makalelerinde toplumsal hareketi "bir sosyal yapının belli yönlerini ve/veya toplumdaki kazanç dağılımını değiştirmeye yönelik bir dizi düşünceler ve inançlar" olarak tanımlayarak kaynak, organizasyon ve strateji konularına odaklanmıştır. Siyasi Süreç Modeli'nin öncülerinden Charles Tilly'ye (2008) göre ise, toplumsal hareketler bir "çekişmeli politika" (contentious politics) biçimidir. Zira toplumsal hareketler, başkalarının çıkarlarıyla çatışacak kolektif hak talepleri içerdiği için "çekişmeli" ve bu hak talepleri bağlamında gücü elinde tutanlara karşı yapılan mücadelelerden dolayı da "politik"tir (2008: 16). Kaynak Mobilizasyonu ve Siyasi Süreç yaklaşımları, toplumsal hareketleri "dışlanmış grupların, kurumsal olmayan yollardan siyasal etki mobilize etmeye yönelik rasyonel girişimleri" olarak tanımlamaktadır (McAdam, 1982: 36-37).

Yeni Toplumsal Hareket (New Social Movement) teorisyenlerinden Alberto Melucci (1999: 87) ise toplumsal hareketleri "dayanışmaya dayalı, bir çatışma taşıyan, yer aldığı sistemin sınırlarını zorlayan bir kolektif hareket 
biçimi” olarak tanımlamıştır. Toplumsal hareketlerin sembolik yönünü öne çıkararak kolektif kimlik inşasına vurgu yapan Melucci'ye (1996) göre, bir hareketin amacı sisteme dâhil olma ya da maddi kazançlar sağlamak değil, toplumda var olan problemlere dikkat çekmek ve yerleşik kültürel normları ve kimlikleri sorgulayarak dönüştürmektir. Benzer şekilde Donatella della Porta ve Mario Diani'ye (2006) göre katılımcıların belli bir kolektif kimliği paylaşıyor olması hareketin oluşumu için temel bir gerekliliktir. Melucci, della Porta ve Diani'nin toplumsal hareket tanımları, katılımcılar arasındaki dayanışma hissi, paylaşılan normlar ve değerler, ortak anlam yaratma ve kimlik inşası süreçlerini öne çıkararak, toplumsal hareket aktörlerini yalnızca çıkarlarının peşinde koşan bir grup olmaktan daha öteye taşımıştır. Bu çalışmada Diani'nin toplumsal hareketler için önerdiği kapsamlı ve esnek tanım kullanılacaktır. Diani'ye (1992: 13) göre toplumsal hareket, toplumsal değişim sağlamak veya değişime karş1 çıkmak amacıyla oluşturulmuş "siyasal veya kültürel bir çatışma içinde olan birden fazla birey, grup ve/veya organizasyon arasındaki paylaşılan bir kimliğe dayalı enformel etkileşimler ağı"dır.

Toplumsal hareket çalışmaları alanında öne çıkan iki kuram bulunmaktadır. Bunlar, 1960'lı yıllardan itibaren yükselişe geçen yeni toplumsal hareketleri — sivil haklar hareketleri, öğrenci hareketleri, çevreci hareketler, etnik kimlik hareketleri, nükleer ve savaş karşıtı hareketler - analiz ihtiyacıyla geliştirilen ABD merkezli Kaynak Mobilizasyonu (Resource Mobilization) ve Avrupa çıkışlı Yeni Toplumsal Hareket (New Social Movement) teorileridir. Kaynak Mobilizasyonu Teorisi (KMT), yoksunlukları ve sıkıntıları toplumsal hareketlerin arkasındaki asıl itici güç olarak kabul eden geleneksel kolektif davranış ekolünün aksine (Morris ve Herring, 1987), mevcut şikâyetlerin ifadesini kolaylaştıran yapısal şartlara odaklanmıştır (McCarthy ve Zald, 1977; Jenkins, 1983; Edwards ve McCarthy, 2004). KMT'ye göre sikıntılar her zaman vardır, ancak bunların toplumsal harekete yol açmasını sağlayan ise erişilebilir kaynaklardaki, grup organizasyonundaki ve kolektif eylem firsatlarındaki değișimlerdir (Jenkins, 1983). Ayrıca KMT, toplumsal hareketler ve harekete katılan bireylerin, çıkar peşindeki rasyonel aktörler olduklarını vurgulamaktadır. İki dala ayrılan KMT'nin iktisat vurgulu kolu hareket oluşumunu incelerken hareket girişimciliği, kaynaklar ve profesyonel toplumsal hareket örgütleri gibi unsurlara odaklanırken, siyasi firsat vurgulu kolu ise siyasal yapilara, firsatlara ve kisitlamalara odaklanmaktadır (Jenkins, 1983).

KMT'nin iktisat vurgulu kolu toplumsal hareketleri incelerken mobilize edilmesi gereken çeşitli kaynaklar, hareket örgütlerinin diğer gruplarla olan bağlantıları, başarı için dışsal desteğe bağımlılık ve hareketleri kontrol etmek için kullanılan taktikler üzerinde durmaktadır (McCarthy ve Zald, 1977). Kolektif davranışın sosyal psikolojisinden uzaklaşan bu yeni teorinin, 
merkezine koyduğu noktalar arasında para, iş gücü, meşruiyet, imkân, altyap1, sosyal ağlar, dayanışma desteği, tecrübe ve kültürel kaynakların temini (Edwards ve McCarthy, 2004), kaynak toplama sürecinde kullanılan ve hareketin devamlılığı için gerekli olan organizasyon yapısı ve toplumsal hareketlere bireysel ve örgütsel katılımı açıklamak için maliyete ve kazanca odaklanma gerekliliği bulunmaktadır (McCarthy ve Zald, 1977; Edwards ve McCarthy, 2004). Bu teoride, ayrica, toplumsal hareketlerin mobilizasyon süreçleri ve stratejileri açıklanırken, harekete katılım için fırsat sağlayan ve hiyerarşik bir yapıya sahip olan profesyonel toplumsal hareket organizasyonları (social movement organizations - SMOs) önemli bir yer tutmaktadır.

Siyasi Süreç Modeli (Political Process Model) olarak da bilinen, KMT’nin siyasi firsatlar odaklı yaklaşımı, mobilizasyon için önemli olan firsat yapılarına işaret ederek, zamanla bu yapılarda meydana gelen değişimlerin, mobilizasyon, protestocuların kullandıkları strateji ve taktikler ve hareketlerin başarıya ulaşma ihtimali üzerindeki etkilerine odaklanmaktadır (Tilly, 1978). $\mathrm{Bu}$ modele göre, toplumsal hareketlerin çıkarlarını ilerletmelerine imkân sağlayan veya engel olan, ekonomik faktörlerden ziyade, siyasi firsat yapılarındaki (political opportunity structures) değişimlerdir (McAdam, 1996; Tarrow, 1998; Meyer, 2004). Siyasal şartlar değiştikçe hak taleplerinde bulunan halk kesimlerine yeni mobilizasyon firsatları doğabilmektedir. Dış kaynaklı firsat ve engellerin değişim halinde olması, bir toplumsal hareketi, mobilizasyon aşamasından olası siyasal etkilerine kadar her yönden etkilemektedir (Meyer, 2004).

Fırsat yapılarına dair çeşitli yaklaşımların varlığı, kavrama dair net bir tanımın yapılmasını zorlaştırmaktadır. Birçok araştırmacı fırsat yapılarına dâhil etmiş oldukları ögeler konusunda birbirlerinden ayrılırlar. Ruud Koopmans'a (1999: 96) göre firsat yapıları, "mobilize olan gruba dişsal olan fakat grubun mobilize olma ve/veya kolektif çıkarlarını gerçekleştirme şansını etkileyen kısıtlamalar, ihtimaller ve tehlikeler"dir. Bazı araştırmacılar bu tanımın kapsamında yalnızca siyasal ögelere yoğunlaşırken (Tarrow, 1998; McAdam, 1996), diğerleri ise çeşitli kültürel (Gamson ve Meyer, 1996) ve söylemsel (Koopmans ve Olzak, 2002) unsurlara da yer vermiştir. McAdam, Tarrow ve Tilly'ye (2009) göre bu firsat yapılarından en önemlileri arasında siyasal sistem içinde birden fazla sayıda bağımsız güç merkezi olması, sistemin yeni aktörlere açılı̆ğı, mevcut siyasal gruplaşmadaki değişimler, eylemcileri destekleyen güçlü müttefiklerin varlığı, devletin baskı yapma kapasitesi ve eğilimi ve tüm bu maddelerdeki belirleyici değişimler bulunmaktadır.

Söylemsel ve kültürel firsat unsurlarına geçmeden önce çerçeveleme yaklaşımından bahsetmek faydalı olacaktır. Çerçeveleme (framing) kavramı toplumsal hareket çalışmalarına 1986 yılında David A. Snow, E. Burke Rochford, Jr., Steven K. Worden ve Robert D. Benford'un "Frame Alignment 
Processes, Micromobilization, and Movement Participation” başlıklı önemli çalışmasıyla girmiştir. Snow ve diğerleri (1986), bu yaklaşımı KMT ve sosyopsikolojik bakış açıları arasında kavramsal bir köprü olarak geliştirmiştir. Bu yaklaşıma göre, çerçeveler, olayları, tecrübeleri ve etkinlikleri anlamlı kılarak eylemi yönlendirme işlevine sahiptir. Kolektif eylem çerçeveleri (collective action frames), hareket destekçilerinin, değişmesi gereken durum ve bu durumun sorumlusu hakkında fikir birliğine ulaşması, soruna dair bir çözüm alternatifi sunmaları ve istenilen değişimi elde etmek için başkalarını beraber hareket etmeye çağırmalarıyla oluşmaktadır (Benford ve Snow, 2000). Çerçeveler, "söylemsel" (discursive), "çekişmeli" (contested) ve "stratejik" (strategic) süreçler yoluyla yaratılmaktadır. Söylemsel süreç, hareket üyelerinin hareketin eylemleriyle ilgili sözlü ve yazılı iletişimini içermektedir. Burada öncelikle bazı olay, mesele ve inançlar diğerlerinden daha ön plana çıkartılarak, olay ve deneyimler arasında bağlantı kurulması yoluyla anlamlı bir bütün oluşturulmaktadır. Çekişmeli süreç ise karşı-çerçeveleme (counter-framing) ve çerçeveleme çekişmeleri (framing contests) aktivitelerini kapsamaktadır. $\mathrm{Bu}$ aktiviteler, grupların belli bir durumu karşıt tarafları gözden düşürmek amacıyla çerçevelemeye çalışmaları sonucu ortaya çıkmaktadır. Son olarak "bilinçli, çıkarcı ve hedef odaklı" stratejik çerçeveleme süreci, üye sayısında artış sağlama, destekçileri mobilize etme ve kaynak sağlama gibi amaçlar elde etmek için geliştirilen ve kullanılan çerçeveler oluşturmayı içermektedir (2000: 624). $\mathrm{Bu}$ noktada toplumda hâkim olan kültürel iklim ve toplumsal hareketlerin medyayla olan ilişkisi, hareketlerin çerçevelerini kitlelere duyurabilmeleri ve halkın gözünde meşruluk kazanabilmeleri açısından önem taşırlar ve birer firsat unsuru oluştururlar.

Fırsat yapılarının analizinde siyasal unsurlara ek olarak söylemsel ve kültürel unsurlara da yer verilmesi gerektiğini düşünen araştırmacılardan Gamson ve Meyer (1996) firsat yapılarının güçlü bir kültürel bileşeni olduğunu ve araştırmanın odağının yalnızca siyasal kurumlardaki ve siyasal aktörlerin ilişkilerindeki değişimlerle sınırlandırılmaması gerektiğini vurgulamaktadır. Karl-Werner Brand (1990), belli dönemlerde hâkim olan kültürel iklimin ve bu iklimdeki değişimlerin çerçeveleme stratejilerine olan etkisine dikkat çeker. Brand, dışsal olayların veya içsel gerginliklerin büyümesinin var olan siyasal fikir birliğini sarsarak çeşitli mücadelelerin ve yeni bir protesto döngüsünün oluşumuna yol açmakta olduğu tespitini yapmaktadır. Başka bir deyişle, değişen sosyo-kültürel şartlar halkın belli toplumsal hareket çerçevelerine ve mesajlarına daha açık olmasını sağlayacaktır. Diğer yandan, medya erişimi ve bilgi akışı da toplumsal hareketler için önemli bir firsat yapısı oluşturabilmektedir (Gamson ve Meyer, 1996; Koopmans ve Olzak, 2002). Koopmans ve Olzak (2002: 8), "söylemsel firsatlar"dan (discursive opportunities) bahsettikleri çalışmalarında "bir mesajın görünürlüğünün kamu 
söylemini etkilemenin gerekli bir şartı” olduğunu vurgulamaktadır. Mesajı görünür kılmak, yayılmasını sağlamak ve diğer aktörlerin ilgisini çekip halktan destek sağlamak için medya gibi iletişim kanallarına ihtiyaç vardır. Bu nedenle medyanın toplumsal hareketlere açıklığı önemli bir firsat unsurudur.

KMT'nin iktisat ve siyasi firsat vurgulu kolları, kolektif davranışı olumsuz ya da irrasyonel olarak nitelendirilmekten kurtarmış, ancak hareketlerin kültürel boyutunu göz ardı ederek anlamlarını incelemede başarısız kalmıştır. KMT’nin özellikle kimlik ve yaşam tarzı savunusu yapan bazı hareketleri anlamada yetersiz kaldığına dair eleștiriler, alanda Yeni Toplumsal Hareket Teorisi'ne (New Social Movement Theory) yer açmıştır. Avrupa kökenli Yeni Toplumsal Hareketler teorisine (YTHT) göre, "post-endüstriyel" toplumlarda ortaya çıkan toplumsal hareketler, bu toplumların sahip oldukları yeni özellikler nedeniyle, eski toplumsal hareketlerden yapıları, destekçileri, hedefleri ve savundukları değerler bakımından farklılık göstermektedir (Touraine, 1985, 1988; Melucci, 1980, 1999, 1996; Habermas, 1981; Cohen, 1999; Castells 1997). Sanayi sonras1 toplumlar, sadece ekonomik temelde yükselmeyen, ekonomik, politik ve kültürel yapıların artarak bütünleştiği bir yerdir (Melucci, 1999). Bu nedenle YTHT, toplumsal hareketlerin sosyokültürel yönüne odaklanmaktadır. Yeni toplumsal hareketler, maddi kazanç sağlamak ya da siyasal sisteme katılımlarını arttırmak için değil, sembolik ve kültürel talepleri nedeniyle mücadele etmektedir (Melucci, 1996; Habermas, 1981; Cohen, 1999). Eski hareketlerden farklı olarak, yeni hareketlerin vurguladığ 1 değerler arasında kültür, kimlik, yaşam tarzının önemi, adem-i merkeziyetçilik ve otonomi vardır. Asıl işlevleri siyasal güç veya kontrol elde etmek değil, onun yerine sisteme sorular yöneltmek, gücü görünür kılmak ve topluma bir problemin varlığını ve alternatif modellerin, normların ve yaşam tarzlarının mümkün olduğunu göstermektir (Melucci, 1996). Örgütlenme ve mobilizasyon biçimleri çoğunlukla enformel ağlara dayalı olan bu hareketlerin resmi ve profesyonel organizasyonları yoktur. Merkezi ve hiyerarşik bir sistem yerine çeşitli otonom birimleri birbirine bağlayan iletişim ağlarına sahiptirler. Belirlenmiş bir hiyerarşi olmadığı gibi farklı bireyler farklı zamanlarda hareketin sözcüsü görevini üstlenebilmektedir. Hareket alanları ise değerlerin, normların ve kimliklerin inşa edildiği sivil toplumdur (Cohen, 1999; Offe, 1999).

Zaman içinde kolektif eylem çerçeveleri, kolektif kimlik ve sosyal ağlar gibi kültürel ögeler de, siyasi firsat ve ekonomi merkezli yaklaşımlara dâhil olarak bunların sınırlarının genişlemesine sebep olmuş, bunun sonucu olarak toplumsal hareket çalışmalarının temel kuramları birbirlerine yaklaşmıştır (Çetinkaya, 2008). Toplumsal hareket teorisyenleri değişmekte olan şartlaraneoliberal küreselleşme, giderek daha çeşitli hale gelen toplumlar, yeni iletişim teknolojilerinin yaygın kullanımı vb.- göre teorilerin çerçevelerini 
genişletmeye ve bu değişimlerin toplumsal hareketler için anlamını analiz etmeye devam etmektedir. $\mathrm{Bu}$ çalışma da toplumsal hareketler tarafindan kullanılan yeni BİT'in bu hareketlere etkilerini inceleyerek ilgili literatüre katkı yapmayı amaçlamaktadır.

\section{Yeni Bilgi ve İletişim Teknolojileri (BiT) ve Ağ Toplumu}

Giderek günlük hayatın vazgeçilmez bir parçası haline gelen yeni Bilgi ve İletişim Teknolojileri, çeşitli formlarıyla çoğu toplumun bilgi üretim, erişim ve kullanım kapasitelerini önemli ölçüde arttırarak, bilgi transferini ve edinimini hızlandıran ve kolaylaştıran firsatlar sağlamaktadır (Ogunsola, 2015). Oldukça kapsamlı bir terim olan Bilgi ve İletişim Teknolojileri basitçe, "elektronik yollarla veri iletiminde, idaresinde ve depolanmasında kullanılan teknolojiler" olarak tanımlanabilir (The Open University, 2005). 1970'li yıllardan itibaren şekillenmeye başlayan ve toplumların işleyişini derinden etkileyen teknolojik yenilikler, yeni bir toplum yapısını beraberinde getirmektedir (Webster, 2006). Manuel Castells'e (2005: 4) göre yeni olan, eski toplumsal organizasyon biçimleri için yeni imkânlar sağlayan ağlardır: "Dijital ağ iletişimi teknolojileri, ağların tarihsel kısıtlamalarını aşmalarını sağlamaktadır". Bu nedenle Castells, bu yeni toplum yapısından söz ederken "ağ toplumu" (network society) terimini kullanmaktadır. Ağ toplumu, "temel toplumsal yapıların ve aktivitelerin elektronik olarak işlenen enformasyon ağları etrafında organize olduğu" bir yapıdadır (2005: 4). Castells'e göre teknoloji toplumu şekillendirmez, aksine, teknolojiyi kullanan insanların ihtiyaçlarına, değerlerine ve çıarlarına göre toplum teknolojiyi şekillendirmektedir.

A $\breve{g}$ toplumunun en önemli özelliklerinden biri iletişimin değişen doğasıdır. Ağ toplumunda iletişim, giderek daha interaktif ve dijital bir yapıya sahip olmuştur. BİT'in yardımıyla "sanal zaman ve mekânlar yaratmak ve aynı anda hem küresel hem de yerel koşullarda düşünmek ve davranmak" mümkün hale gelmiştir (Van Dijk, 2006: 36). Geleneksel toplumlar birbirine coğrafi yakınlığı bulunan bireyler arasındaki doğrudan etkileşime dayalıyken, çağdaş toplumlardaki zaman ve mekân bariyerleri, iletişim ve taşıma alanlarının giderek artan erişim kabiliyeti sayesinde kırılmaktadır (2006). Yeni iletişim teknolojilerinin yayılmasıyla ve yatay iletişim ağlarında meydana gelen patlama sayesinde Castells'in (2005) "öz-güdümlü kitle iletişimi”" (self-directed mass communication) adını verdiği bir olgu ortaya çıkmıştır. Böylece, ă̆ toplumunda, hükümetlerden ve medya şirketlerinden bağımsız bir kamu alanının varlığı siyasal süreci dönüşüme uğratmıştır. Zira siyasal fikirler ve davranışlar iletişim alanında şekillenmektedir. 
Internet ve yeni medya unsurları, bilgiye hılı ve kolay erişim ve çevrimiçi platformlarda diğer bireylerle etkileşimli iletişim kurma imkânlarına olanak vererek sivil toplumun gelişimine ve var olan kamusal alanın yeniden şekillenmesine katkıda bulunmaktadır. Bu sayede, hükümetlerin ve anaakım medya kanallarının etkisinden uzak sanal ortamlarda tartışmak, gruplar kurmak, fikir alı̧serişinde bulunmak ve alternatif kamusal alanlar yaratmak artık mümkün hale gelmiştir. Özellikle Internet'in yaygın kullanımı ile hayatımıza giren bloglar, sosyal medya platformları, çevrimiçi gazeteler ve forumlar gibi yeni medya ögeleri sayesinde insanlar yerel, ulusal ve ulusötesi gelişmeleri gerçek zamanlı olarak takip edebilmek, alternatif haber kaynaklarına ulaşmak ve fikirlerini ve eserlerini paylaşacak yeni araçlar edinmek için yeni firsat ve alanlara kavuşmuştur. Bunun sonucunda coğrafi yakınlığın değil paylaşılan görüş, değer ve kimliklerin bir araya getirdiği yerel, ulusal ve ulusötesi topluluklar ve hareketler oluşturmak daha kolay hale gelmiştir. Yeni bilgi ve iletişim araçları bireylere haber alma, bilgi toplama ve yayımlama konusunda aktif rol oynama firsatı sunarak, vatandaşlara, bağımsız gazetecilere ve diğer alternatif haber kaynaklarına kitleler tarafından duyulma imkânı vermiştir.

\section{Toplumsal Hareketler ve Yeni Bilgi ve İletişim Teknolojileri}

Yeni BİT'in ortaya çıkışı ve yaygın kullanımıyla toplumsal hareketlerin geleneksel basın yayın organlarına olan ihtiyacı ve bağımlılıkları belirli ölçüde azalmıştır. Yeni medyanın toplumsal hareketler tarafından kullanımı, iletişim konusunda çeşitli avantajlar, firsatlar ve özgürlükler sağlayarak toplumsal hareketlerin kapasitelerini ve etki alanlarını önemli ölçüde arttırmıştır. Toplumsal hareketler, yeni medyanın getirdiği alternatif iletişim kanalları yoluyla, geleneksel medyayı atlayarak, görüşlerini halka doğrudan aktarabilme imkânına sahip olmuştur (Garrett, 2006; Bennett, 2005; Spier, 2011; Harlow, 2011). Ayrıca bireyler arasındaki temel bağlantıların kurulması ve devam ettirilmesi için gerekli olan ortamı sağlayan sosyal alanların kapsamı genişlemiştir. Sosyal alanların çevrimiçi ortamlara uzanması ile ortaya çıkan çeşitli Internet siteleri, sosyal medya ağları, e-posta listeleri, forumlar gibi interaktif iletişim platformları sosyal hareketin difüzyon sürecinde önemli rol oynayabilmektedir. Ayrıca kolektif eylem gruplarının örgütlenme ve koordinasyon süreçleri kolaylaşarak coğrafi uzaklıklar mobilizasyon için engel olmaktan çıkmıştır. Bu bölümde yeni BİT'in toplumsal hareketler için oluşturduğu firsatlar, avantajlar ve dezavantajlar dört başlık altında incelenecektir. 


\subsection{Toplumsal Hareketler ve Medya}

Toplumsal hareketler ve medya arasında karşılıklı bağımlılığa dayanan bir ilişki vardır. Medya, toplumsal hareketlerin mesajlarını duyurmalarına yardımcı olabilecek önemli bir araç ve platformken toplumsal hareketler de medya için değerli haber kaynakları oluşturmaktadır. Medyanın tek rolü toplumsal hareketler için araç görevi görmek değildir. Medya aynı zamanda gerçeklik inşasının yapıldığı bir alan (Brasted, 2005; Boykoff, 2006), sorunları ele alış şekliyle anlam inşasında rol oynayan bir araç ve sorunların meşru olarak tanımlandığı veya reddedildiği bir platform (Gamson ve Meyer, 1996) görevi görerek, halk tarafından olayların nasıl algılanıp yorumlanacağında belirleyici olmaktadır (Cooper, 2002). Alice Cooper'a (2002: 40) göre, "sorunların algılanış şekli sosyal olarak inşa ediliyorsa, yani hareket tarafından nüfuza açıksa, çerçeveleme, hareket örgütleri için çok önemli bir stratejik aktivitedir". Dolayısıyla, toplumsal hareketlerin medya tarafindan yayımlanması ve temsil ediliş biçimi veya tamamen görmezden geliniyor olması hareketlerin biçimini, gelişimini ve hedeflerine ulaşma şanslarını büyük ölçüde etkilemektedir.

Toplumsal hareketlerin daha fazla potansiyel destekçiye ulaşmak, varlıklarını ve seslerini duyurmak, büyümek ve yayılmak için yayımlanmaya ihtiyaçları vardır. Medyanın ilgisini çekmeyi başarmış bir hareket geçici bir firsat penceresi yakalayarak (Gamson ve Meyer, 1996) siyasal aktörlerle diyaloğa girme, destekçi ve katılımcılarını arttırma ve kaynak ve bağış sağlama gibi firsatlar elde edebilmektedir (Vliegenthart ve Walgrave, 2012). Hareketler medya tarafından kitlelere olumlu bir ışı altında sunulacakları garantisine sahip olmasa da, görünürlük kazanmış olan bir hareketin varlığı ve iddiaları artık meşrulaşmıştır. Bu da hareketi siyasi güç sahiplerinin gözünde önemli bir aktör haline getirmektedir. Ancak ne yazık ki bir hareket, yeniliğini ve/veya haber değerini kaybettiğinde bu firsat penceresi kapanmaktadır (Gamson ve Meyer, 1996). Bu nedenle toplumsal hareketler, medyanın seçiciliğini aşarak yayımlanabilmek için medyanın gözünde haber değeri olan yeni, yaratıcı ve dikkat çekici eylem ve protesto biçimleri yaratmak gibi stratejiler geliştirmektedir (Gamson ve Meyer, 1996; Cooper, 2002; Boykoff, 2006; Vliegenthart ve Walgrave, 2012). Beraberinde bazı tehlikeleri de beraberinde getiren bu taktikler toplumsal hareketlerin imajı için sakıncalı olabilmektedir. Zira bu hareketler yayımlanmayı başarsalar bile medya tarafindan nasıl temsil edildiklerini kontrol edememektedir. Çoğu zaman medya, hareketin mesajına ve odaklandığı sorunlara yer vermeyerek ve/veya azınlıktaki uç gruplara odaklanıp yanlış tasvirlerde bulunarak hareketin çerçevesine zarar verebilmektedir (Cooper, 2002; Boykoff, 2006; Vliegenthart ve Walgrave, 2012). Örneğin, bir hareketin gerçekleştirdiği geniş bir protestoyu resmederken, medya eyleme katılanlar arasındaki az sayıdaki taşkın ve şiddete eğilimli bireyin yaptıklarına odaklanarak hareketi negatif bir 1şıkta göstermeyi 
seçebilmektedir (Hertog ve McLeod, 1995; McLeod ve Detenber, 1999; Chan ve Pan, 2003). Haber yayınının içeriği hareketlerin mobilizasyon şansını büyük ölçüde etkilemektedir. Medya çerçevesinin hareket çerçevesiyle uyum içinde olduğu nadir durumlarda mobilizasyon oldukça artarken, uyumsuzluğun veya karşı-çerçevelemenin söz konusu olduğu durumlarda bunun tam tersi söz konusudur (Cooper, 2002).

\subsection{Yeni Bit ile Değişen İletişim, Mobilizasyon ve Protesto Dinamikleri}

Yeni BİT'in yükselişiyle toplumsal hareketler ve medya arasındaki ilişki dönüşüme uğramıştır. Toplumsal hareketler artık, yeni medyanın getirdiği alternatif iletişim kanalları yoluyla, savundukları ve/veya karşı oldukları konuları herhangi bir aracıya ihtiyaç duymadan, çevrimiçi ağlar üzerinden kitlelere doğrudan aktarabilme imkânına sahiptir (Garrett, 2006; Spier, 2011; Harlow, 2011). Toplumsal hareketler böylece, mesajlarını medya şirketlerinin kontrolüne veya düzenlemelerine maruz kalmadan yayarak, hareketin tartışıldığ üslubu biçimlendirme firsatı elde etmiştir (Van Aelst ve Walgrave, 2004; Garrett, 2006). Bununla beraber, toplumsal hareketlerin yeni medya ögelerini kullanarak halkın dikkatini çekmeye başlamaları, konunun anaakım medyanın gündemini etkileyerek, yerel ve/veya uluslararası medya organları tarafindan yayımlanma ihtimalini arttırabilmektedir (Garrett, 2006; Eltantawy ve Wiest, 2011). Daha önceden çevrimiçi ortamlarla sınırlı olan içeriklerin bu yolla geleneksel medyaya taşması, halkın harekete dair farkındalığını ve bilgisini sosyal medya platformları dışında da arttırmaktadır (Spier, 2011; Breuer, 2012). Ayrıca Internet'teki yayınların çoğu erişime sürekli açık olduğundan, konuyla ilgilenen bireyler, anaakım medyanın ilgisi başka konulara kaydıktan sonra dahi istedikleri bilgilere, haberlere ve içeriklere erişebilmektedir (Garrett, 2006).

Bir başka açıdan ise yeni BİT, otoriter rejimlerdeki basın yayın organları üzerindeki hükümet kontrolünü ve/veya sansür uygulamalarını aşma konusunda da faydalı olmaktadır. Toplumsal hareketler, dijital teknolojiler yardımıyla seslerini duyurarak, hükümetlerin halktan gizlemek istedikleri veya çarpitarak aktarmaya çalıştıkları gerçeklerin kitlelere ulaşmasını sağlayabilmektedir (Garrett, 2006; Breuer, 2012; Tüfekçi, 2014). Sosyal medya siteleri, kolayca erişilebilen yapıları nedeniyle vatandaş gazeteciliği veya katılımcı gazetecilik amaçlarıyla kullanılabilen platformlara dönüşmüştür (Eltantawy ve Wiest, 2011; Harlow, 2011; Storck, 2011). Gerektiğinde kamusal alanın çevrimiçi ortamdaki bir uzantısı haline gelebilen bu siteler sayesinde, hareket grupları ve aktivistler, hükümet tarafından dayatılmakta olan baskı ve sansür atmosferine karşı durarak, onun dayatmaya çalıştığı söyleme ve siyasi dile alternatif olacak 
bir seçenek sunmaktadırlar (Harlow, 2011). Böylece insanların, olayları farklı bir bakış açısıyla yorumlamaları mümkün olacaktır. Yine de, geleneksel medyanın kamusal alanda hâlâ oldukça önemli bir yere sahip olduğu unutulmamalıdır. Yeni medyanın yükselişiyle gücünde belli bir ölçüde azalma meydana gelmiş olsa da, geleneksel medyanın etkisi küçümsenmemelidir.

Yeni BİT, profesyonel toplumsal hareket organizasyonlar1 ve tabandan gelen toplumsal hareketler tarafindan dışsal iletişime ek olarak sosyal ağlar, koordinasyon, örgütlenme ve protesto alanlarında da kullanılmaktadır. Özellikle toplumsal hareketler tarafindan birer mobilizasyon ve organizasyon aracı olarak kullanılan çevrimiçi sosyal ağlar, hareketler için oldukça işlevsel bir rol üstlenmektedir. Yeni BIT'in toplumsal hareketlerin mobilizasyon süreçlerine olan etkilerinden bahsetmeden önce mobilizasyon kavramını incelemek faydalı olacaktır. Mobilizasyon yapıları (mobilization structures) bireylerin mobilize olduğu ve kolektif eyleme geçtiği resmi ve/veya gayri resmi kolektif araçlardır (McAdam, 1996). Bunların arasında toplumsal hareket organizasyonları, sendikalar ve dernekler gibi çeşitli sivil toplum kuruluşları (STK), kulüpler ve potansiyel aktivistler arasında oluşmuş resmi olmayan sosyal ağlar vardır. Tarrow (1998) ise mobilizasyon yapılarından söz ederken öncelikle bir hareketin çıkarları için çalışan resmi ve hiyerarşik yapıya sahip örgütlerden bahsetmektedir. $\mathrm{Bu}$ örgütlerin stratejik görevleri arasında destekçileri mobilize etmek, kaynak sağlamak, halkın ve seçkinlerin desteğini kazanmak, hareketin hedeflerini gerçekleştirmek için çalışmak (McCarthy ve Zald, 1977), koalisyonlar oluşturmak ve etkinlikleri koordine etmek (Tarrow, 1998) vardır. Bunun dışında, mobilizasyon yapılarının varlığı hareketlerin devamlılığını sağlamak, durağan dönemlerde ayakta kalabilmek ve olası firsatlardan faydalanmaya hazır durumda olmak için de oldukça önemlidir (Kriesi, 1996).

Yeni BİT'in kolektif eylemleri organize etme ve uygulamada kullanılmaya başlanması toplumsal hareketlerin kapasitelerini ve etki alanlarını önemli ölçüde genişletmiştir. Kolektif eylem grupları, yeni teknolojileri kullanarak, eskiden beri sürdürmekte oldukları işlevleri daha etkili, daha hızlı, daha yaratıcı ve daha az maliyetli bir biçimde gerçekleştirebilmektedir. Toplumsal hareketin birtakım temel süreçlerini gerçekleştirmek, yeni medya ögeleri sayesinde göreceli olarak daha ufak boyuttaki gruplar için dahi mümkün hale gelmiştir. $\mathrm{Bu}$ süreçlere örnek olarak, kitlelere hareketin doğası ve amaçlarıyla ilgili bilgi sunmak, insanlara katılım için çeşitli giriş noktaları sağlamak, diğer gruplarla stratejik bağlar kurmak ve eylem organizasyonu aşamasında geniş ölçekli koordinasyon sağlamak gösterilebilir. Toplumsal hareketler, yeni BİT'in etkisiyle eskinin hiyerarşik ve merkezi yönetim biçimlerine ihtiyaç duymadan, geleneksel liderlik yapılarının getirdiği kısıtlamalardan daha az etkilenerek işleyebilmektedir (Garrett, 2006). Günümüz toplumsal hareketleri artık gerçek zamanlı ve daha hızlı organize edilebilen 
protestolar, ademi-merkeziyetçi örgütsel biçimler, lidersizlik veya değişimli liderlik, örgüt içinde ve aktivistler arasında kolay ve hızlı iletişim ve dijital aktivizm gibi özelliklerle karakterize olmuştur. Örneğin, Mısır Devrimi sırasında, 25 Ocak'taki protestoların önde gelen organizasyonel kaynaklarından biri, destek sağlamak ve koordinasyon için büyük oranda Facebook ve diğer sosyal medya ağlarından yararlanan "6 Nisan Hareketi" (the April 6 Movement) adl1 grup olmuştur (Eltantawy ve Wiest, 2011). Grup üyelerinin, gösterilerin hazırlık aşamasında şiddet içermeyen mücadelelerle ilgili Internet üzerinden edindikleri bilgiler, protesto etkinliklerine daha iyi hazırlanmalarını sağlamıştır. Yine 1999 yılında Seattle'daki neoliberal küreselleşme karşıtı gösteriler sırasında, örgütlerin Internet sitelerinin büyük çoğunluğu, sağladıkları bilgilendirme içerikleri ve çevrimiçi kayıt formlarıyla üye ve destekçi sayılarını artırmayı hedeflemiştir. Bunlara ek olarak, protestolarda aktif rol almak isteyen bireyler, gösterilerin yeri, saati ve gösteri alanına nasıl ulaşılacağı gibi konulara yönelik bilgilere örgütlerin Internet siteleri üzerinden erişilebilmiştir (Van Aelst ve Walgrave, 2004).

Mobilizasyon yapıları arasında sosyal ağlar büyük öneme sahiptir. Zira sosyal ağlar bir toplumsal hareketin oluşumunu, gelişimini ve devamlılığını önemli ölçüde etkileyen unsurlardır. Toplumsal hareket organizasyonları, mobilizasyon yapılarının temeli olarak görülse de, bireyler arasındaki ağlar da hareketler için önemli sosyal altyapılardır. Hareket oluşumu ve katılımcı sağlama, büyük ölçüde yerel mücadelenin, dayanışma ve ortak kimlik duygusunun oluştuğu bu seviyede meydana gelmektedir. Bireylerden, etkinliklerden, organizasyonlardan ya da daha büyük birimlerden meydana gelebilen bu ağlar, tanımlanması kolay olmayan karmaşık ve çok boyutlu yapılardır. Diani (2003) sosyal ağların yapısını incelerken üç kategoriden bahseder: Bireyler arasındaki ağlar, örgütler arasındaki ağlar ve etkinlik ağları. Florence Passy'ye (2003) göre ağların katılıma etki eden üç işlevi vardır. Bunlardan ilki sosyalleşme fonksiyonudur: Bireyler sosyal ağlar yoluyla siyasal bilinç kazanarak belli bir siyasal meseleye yakınlık duyabilmektedir. Aktörler, sosyal etkileşimler yoluyla sosyal gerçekliği yorumlayarak eylemlerine karar vermektedir (Diani, 2003; Passy, 2003). Ancak katılım firsatı elde etmedikleri sürece bu tek başına yeterli olmayacaktır. Bu aşamada ikinci işlev olan yapısal bağlantı fonksiyonu devreye girmektedir. Passy (2003) burada ağların potansiyel katılımcıları yapısal olarak bir organizasyona bağlama rolünden bahsetmektedir. Dağıtımı ağlar tarafindan sağlanan devam eden aktivitelere, var olan organizasyonlara ve katılım maliyetlerine dair bilgiler katılım için firsat oluşturmaktadır (Snow, Zurcher ve Ekland-Olson, 1980; Diani, 2003; Passy, 2003). En son evrede ise karar biçimlendirme fonksiyonu vardır. Passy'e (2003) göre firsat evresinden sonra katılım gerçekleşmeden önce kişi bireysel maliyetleri de hesaba katarak bazı kararlar vermektedir. Snow, Zurcher ve 
Ekland-Olson'a (1980) göre bir toplumsal hareket üyesiyle arasında sosyal bağ bulunan bir bireyin, harekete katılması için erişilebilir olması gerekmektedir. Bireyin harekete katılmasının önünde engel olacak başka bağl1lıkları ve sorumlulukları olmamalıdır. Böylece, bireyin, hareket üyeleriyle girmiş olduğu yoğun etkileşim süreci katılım için gerekli olan motivasyonu sağlayabilmektedir.

Yeni BİT sayesinde bireyler arasındaki temel bağlantıların kurulması ve devam ettirilmesi için gerekli olan ortamı sağlayan sosyal alanların kapsamı genişlemiştir. Sosyal alanların çevrimiçi ortamlara uzanmasıyla sosyal medya ağları, tartışma listeleri, forumlar gibi interaktif iletişim platformları ortaya çıkmıştır. Ortak çıkarlara, amaçlara ve kimliklere sahip olan insanlar ve gruplar arasında bağ kurmaya yarayan dijital platformlar, bireylerin var olan sosyal ağlarını genişletmelerini ve yeni ağlar oluşturmalarını kolaylaşmıştır (Spier, 2011). Bu tarz siteler üzerinden, benzer ilgilere sahip bireyler birbirleriyle bağlantıya geçme (Spier, 2011), bilgi ve fikir alışverişlerinde bulunma (Eltantawy ve Wiest, 2011), paylaşılan farkındalığı artırma, çeşitli sorunlar hakkında tartışma (Spier, 2011) ve bunlara alternatif çözümler üretme (Harlow, 2011) imkânı yakalamaktadırlar. Çevrimiçi sosyal ağlarda edinilen bağlantılar ve paylaşılan deneyimler, gerçek dünyada kolektif eyleme katılmak için motivasyon ve firsat sağlamaktadır (Harlow; 2011). Harlow'a (2011) göre Facebook ortamında, grup içinde yapılan yorumlar için sunulan "beğen" ve "yorum yap" seçenekleri münazara ortamı oluşturmaya ve kolektif kimlik duygularının inşasına yardımcı olmaktadır. Sosyal medya platformlarının etkileşimli iletişime olanak veren özellikleri, hareket katılımcıları arasındaki bağların güçlenmesini sağlayarak, çevrimdışı katılım ihtimalini arttırmaktadır. Geleneksel topluluklarda olduğu gibi sanal topluluklarda da karşıllklı etkileşimler, duygusal bağlar, paylaşılan değerler ve ortak kimlik algısı bireyler arasında aidiyet, bağl1lık ve bir amaç sahibi olma hislerini teşvik etmektedir.

Dijital sosyal ağlar bir yandan yalnızca sanal ortamda varlığını sürdüren çevrimiçi toplulukları birbirine bağlamaya yararken, diğer yandan da çevrimdışı toplulukların iletişim sürecini kolaylaştırmaktadır. Yasemin Devrimi'nin 19982010 y1lları arasındaki hazırlık evresi boyunca Internet, Tunus'ta kamusal alanın yönetim tarafından kontrolüne karşı çıkan ve ülkedeki siyasal şartları eleştiren dijital aktivistler arasındaki kişisel ağların oluşumunu kolaylaştırmıştır (Breuer, 2012). Protesto aşamasında ise sosyal medya ağlarının, yönetimin göstericilere verdiği sert tepkiyi açıkça gözler önüne sermesi, toplumun daha önceden kayıtsız olan kesimlerinin duygusal mobilizasyonuna yol açmıştır (2012). Benzer şekilde, Mısır Devrimi sürecinde aktivistlerin 2009 yılından beri ülkedeki sosyo-politik şartlar hakkında çevrimiçi tartışmalar gerçekleştirmekte olduğu gözlemlenmiştir (Eltantawy ve Wiest, 2011). İlerleyen zamanlarda Facebook, Twitter ve çeşitli bloglarda dolaşan mesajlar ve resimler tüm 
dünyadaki Mısırlıların kolektif kimliğini ve aktivistler arasındaki ulusal ve ulusötesi bağları güçlendirmiştir. Her yerden sosyal medya yoluyla iletilen destek ve teşvik mesajları Mısırlı protestoculara motivasyon ve ilham kaynağı olmuş, kendilerini soyutlanmış hissetmelerini engellemiştir (2011).

Ancak yeni BİT'in sağladığı bu avantajlar sanal toplulukların geleneksel toplulukların yerini almaya hazır oldukları anlamına gelmemektedir. Birçok araştırmacıya göre (Diani, 2000; Parks, 2011) doğrudan yüz yüze iletişimin sicaklığ1 ve yoğunluğundan yoksun olan sanal topluluklar, oldukça sinırlı yapıları gereğiyle varlıklarını devam ettirebilmek için geleneksel topluluklara ihtiyaç duymaktadır. $\mathrm{Bu}$ nedenle bir topluluğun devamı için ideal olan, çevrimiçi ve çevrimdışı sosyal bağların birbirini desteklemesidir (Van Dijk, 2006).

\subsection{Ulusötesi Toplumsal Hareketler ve Yeni BiT}

Protesto grupları ve aktivistler, ulus-devletin yetersiz veya etkisiz kaldığını düşündükleri durumlarda yeni iletişim teknolojileri aracılığıyla organize olarak, küresel arenada hareket eden aktörler haline gelebilmektedir. Küresel Adalet Hareketi (Global Justice Movement) örneğinde de gözlemlendiği gibi, dünyanın çeşitli ülkelerine mensup onbinlerce insan, bölgesel ve küresel ekonomik ve siyasal kurumların yeterli demokratik kontrole tabi olmadığından şikâyet ederek yeni BİT yardımıyla organize olarak Seattle'da bir araya gelmiş ve neoliberal küreselleşmeye karşı çıkmıştır. Internet tabanlı iletişim teknolojileri sayesinde toplumsal hareketler ve aktivistler, coğrafi kısıtlamaları aşıp benzer düşüncedeki bireyler ve eylem gruplarıyla bölgesel veya küresel ölçekli stratejik koalisyonlar oluşturarak yerelin ötesine geçebilmektedir. Bu sayede kendi otonomilerini inşa ederek ulusal ve/veya ulusötesi kurumların ve/veya şirketlerin karşısına çıkabilen ulusötesi kolektif eylem grupları, dünya kamuoyunu etkileyerek mücadeleleri için uluslararası destek sağlayabilmektedir (Castells, 2007; Carty, 2015). Örneğin, 2002 yılında Sidney'deki Hilton Oteli'nin bakım ve onarım çalışmalarını gerekçe göstererek çalışanlarını işten çıkarması sonrasında başlatılan siber kampanyayla otel ve işçiler arasındaki yerel çekişme ulusötesi bir mücadeleye dönüşmüştür. Kısa süre içinde dünyanın çeşitli yerlerindeki insanlardan 3000'den fazla protesto mesajı alan Hilton grubu, işten çıkardığ 1 çalışanlarını yeniden işe almıştır. Binlerce insanın çevrimiçi yollardan verdiği destek ve böylece olayın anaakım medya organlarında yer alması, yönetimin üzerinde baskı oluşturarak ibreyi yerel sendikanın tarafına döndüren faktör olmuştur (Cammaerts, 2005).

Yeni BİT aracılığıyla oluşturdukları ulusötesi kamusal alanlar ve koalisyonlar, toplumsal hareketlere görev sorumluluğunu dağıtma ve dünyanın 
çeşitli yerlerindeki destekçilerin ve aktivistlerin gönüllü çabalarından yararlanma imkânı sunmaktadır (Cammaerts, 2005). Ayrıca, protesto gruplarının oluşturdukları çevrimiçi bilgi ve planlama ağları sayesinde görev ve eylem yükünün tamamının tek bir gruba bırakılmaması ve çeşitli yerel grupların daha büyük bir kolektif hareketin parçası olarak işlev görmesi, hareketin kaynak yeterliliği ve sürdürülebilirliği açısından da fayda sağlamaktadır. Örneğin, Küresel Adalet Hareketi'nin protesto ve eylemlerinin dünyanın çeşitli yerlerinde düzenli aralıklarla meydana geldiği, ancak tek bir noktada uzun dönemli bir aktivitenin olmadığı görülmektedir. Çevrimiçi platformlar üzerinden oluşturulan eylem takvimlerine göre belirli bir noktada yılda en fazla birkaç eylem ve/veya etkinlik gerçekleştirilmiştir (Garrett, 2006).

Protesto ağları yayılmaya ve genişlemeye başladıkça toplumsal hareketlerde ölçek değişimi (scale shift) meydana gelmektedir (McAdam, Tarrow ve Tilly, 2001). McAdam, Tarrow ve Tilly, ölçek değişimi sürecinde üç önemli mekanizmadan bahsetmektedir: Dağınık protesto merkezleri arasında sosyal bağlar kurmaya yarayan aracılık (brokerage) mekanizması, bu bağlar üzerinden sağlanan bilgi akışını tarif eden yayılma (diffusion) mekanizması ve aktivistler arasındaki ortak amaç ve kimlik algısından bahseden benzerlik atfetme (attribution of similarity) mekanizması. Ulusötesi toplumsal hareketler söz konusu olduğunda ölçek değişiminin gerçekleşmesinde dijital iletişim ağları önemli rol oynamaktadır. Başarılı bir ölçek değişiminin sağlanabilmesi için, genişlemekte olan grup koalisyonlarıyla uyumlu olacak yeni kimlik çerçeveleri konusunda uzlaşma elde edilebilmesi oldukça önemlidir. Dijital ağlara bağlanmanın kolaylığı, hareketin ölçeği büyüdükçe kolektif kimlik çerçevelerinin tekrar tekrar müzakere edilmesi gerekliliğini de ortadan kaldırmaktadır (Bennett, 2005). Seattle örneğinde de görüldüğü üzere, çevrimiçi bilgi ve planlama ağlarının varlığı kişisel sürtüşmeleri yatıştırarak kırılgan ilişkileri güçlendirmeye yaramıştır. Böylece hareketin ölçeği gittikçe artarken Küresel Adalet Hareketi ağları, bireysel seviyedeki siyasal kimlikler göz önüne alındığında, hatırı sayılır derecede çeşitliliğe sahip olabilmiştir.

Her ne kadar dijital iletişim ağları ulusötesi toplumsal hareketler için önemli işlevler yerine getiriyor olsalar da, çevrimiçi forumlar ve benzeri tartışma platformları ulusötesi bir kamusal alanın inşası noktasında yetersiz kalmaktadır. Ulusötesi toplumsal hareketler söz konusu olduğunda kültürel farklılıklar ve dil engeli gibi konular sorun teşkil edebilmektedir (Cammaerts, 2005). Hareket bünyesindeki eylem grupları birden fazla dilde bilgi sağlama ve gönüllü çevirmenlerle bu engeli aşmaya gayret etse de, bu her zaman yeterli olmamaktadır. Tüm organizasyonlar belli ölçüde ulusötesi varlığa sahip olsa da, gelişmekte olan ülkelerin yerel eylem grupları daha az temsil edilmektedir. Ayrıca bu ortamlardaki karş1ıklı etkileşim ve tartışma oranı çoğunlukla düşük olmakta ve sınırlı sayıda katılımcı sorunları aralarında gerçek anlamda 
tartışmaktadır. Dahası çevrimiçi forumlar çoğunlukla çevrimdışı dünyada zaten siyasal anlamda aktif bireyler tarafindan domine edilmektedir. Bu nedenle çevrimdışı iletişim hâlâ oldukça önemli bir faktördür. Uzun ömürlü ve başarılı toplumsal hareket organizasyonlarının çoğunluğu birçok örgütsel işlevi çevrimiçi platformlar üzerinden gerçekleştirirken, belirli aralıklarla yüz yüze toplantılar da düzenlemektedir. Bu durum, birebir iletişimin sosyal bağlar ve aktivistler arasındaki güven inşası açısından önemine işaret etmektedir (Cammaerts, 2005; Diani, 2000; Parks, 2011).

\subsection{Yeni BiT'in Beraberinde Getirdiği Dezavantajlar}

Yukarıda bahsettiğimiz faydaların yanı sıra, toplumsal hareket gruplarının ve aktivistlerin yeni medya araçları kullanımı, bazı dezavantajları ve karşı hareketleri de beraberinde getirmektedir. Örneğin, Internet sayesinde kitlesel bilgi dağıtımındaki bariyerlerin azalması bilgi kirliliğine neden olup, neyin gerçek neyin asılsız olduğunu ayırt etmeyi zorlaştırmaktadır (Garrett, 2006; Spier, 2011). Sosyal medya ve blog paylaşımları her zaman gazetecilik standartlarının rehberliğinde yapılmadığından dolayı, her paylaşımı veya yayını doğrulamak mümkün olamamaktadır (Storck, 2011). Bu şartlar altında, ası1sız dedikoduların veya aslı olmayan bilgilerin hızla yayılması riski göz ardı edilmemelidir. Diğer yandan hükümetler, muhalif düşüncelerin ve eylemlerin yayılmasını sınırlandırmak için Internet tabanlı iletişim teknolojilerine karşı yeni kontrol ve gözlem mekanizmaları geliştirmiştir. Stratejilerini adapte ederek sansürleme aktivitelerini çevrimiçi ortamlarda da sürdürmeye çalışan rejimler, ağ yapısını bilgi kontrolü sağlayacak şekilde değiştirme (Garrett, 2006), yasal baskı uygulama, yeni medya araçlarının kötülenmesi ve bu sayede insanların uzak tutulmaya çalışılması, erişimi engelleme ve bu çevrimiçi alanları kendi destekçileriyle doldurma gibi yöntemler kullanmaktadır (Tüfekçi, 2014).

Önceden, daha resmi düzeyde ve daha uzun süreli örgütlenme gerektiren bir takım işlevler artık yeni medya teknolojileri aracılığıyla kolayca gerçekleştirilebilmektedir (Tüfekçi, 2014). Bu nedenle de dijital altyapıların desteğiyle hızlı bir şekilde yükselen toplumsal hareketler, yeterince uzun bir hazırlık döneminden geçmediği için örgütlenme, karar alma ve genel işleyiş̧ dinamikleri açısından zayıf yönlere sahip olabilmektedir. Sivil Haklar Hareketi gibi daha eski hareketler, hareketin ilk evrelerinde geliştirmek durumunda oldukları bu yetenekleri, ileriki zamanlarda yetkililerden baskı gördükleri kritik anlarda sağlıklı manevralar yapmak için kullanabilmiştir. Resmi bir liderlik sistemine sahip olmayan ve dijital teknolojilerin yardımıyla yatay olarak organize olmaya alışmış aktivistler, karar alma konusunda ve siyasal kurumlarla müzakere aşamalarında sıklıkla yetersiz kalmaktadır (Tüfekçi, 2014). 
Yeni BİT'e artan bağımlılığın diğer olumsuz etkileri arasında ise yeni medya üzerindeki hükümet ve/veya elit kontrolü, "slacktivism" ve "hacktivism" konuları dikkat çekmektedir. Yeni medya teknolojilerine yönelik hükümet ve/veya elit kontrolü riskinin altını çizen bazı araştırmacılar, yeni BİT'i kendi amaçları için kullanabilecek tek tarafin aktivistler olmadığına vurgu yapmaktadır (Garrett, 2006; Spier, 2011; Tüfekçi, 2014). Zira hükümetler, bu teknolojileri kullanmak için ihtiyaç duyulan altyapılara ve kaynaklara olan erişimi kontrol altına alarak, tehdit olarak algıladıkları kullanımların önüne geçebilmektedirler. Ayrıca, hükümetlerin yeni medya ağlarındaki mahrem kişisel bilgilere erişmesi durumunda, buradan edinilen bilgilerin, çeşitli aktivistlerin ve protestocuların kimliklerini belirlemek için ve/veya onları takibe almak amaçlı kullanımı söz konusu olabilir.

Yeni iletişim teknolojilerinin istenmeyen yan etkilerinden biri olarak görülen "slacktivism", Internet kullanıcılarının, gerçek bir siyasal eyleme kalkışmadan, çeşitli kampanyalara yalnızca bilgisayar başından "destek" vermeleri durumudur (Morozov, 2009; Spier, 2011). Yeni medya araçları bir meseleyle ilgili farkındalık yaratma konusunda oldukça başarılı olsa da, bunu gerçek eyleme dönüştürme aşamasında etkisiz kalabilmektedir (Morozov, 2009). Birey, katılım maliyeti oldukça düşük olan bir sosyal medya grubuna hiç düşünmeden katılabilmekte ve hiç bir şey yapmadan kendisini faydalı ve önemli hissedebilmektedir. Bu durum, bireyin, aynı meseleye daha aktif bir biçimde katkıda bulunmasının önüne geçmektedir. Internet birçok toplumsal hareket örgütü ve kolektif eylem grubu için elzem olsa da, hareketi düzenleyenler ve potansiyel katılımcılar arasındaki iletişim ve ilişki çevrimdışı alana yansımaz ise, hareketin devamlılığı sağlanamayabilir (Spier, 2011).

Siber aktivizmin bir başka yüzü olan "hacktivism" ise genel olarak yeni BİT tabanlı yöntemler aracılığıyla bir siyasal gündeme dikkat çekme ve/veya toplumsal değişim elde etme çabası olarak tanımlanabilir (Mikhaylova, 2014). Ancak bu yeni olgu, yeni iletişim teknolojileri kullanılarak yapılan dijital aktivizm eylemlerinin birer demokratik hak arayışından çıkıp başka bir eyleme dönüşebilme riskini de beraberinde getirebilmektedir. "Hacktivism" her zaman açık ve demokratik olmamakla beraber çoğu zaman hesap verme zorunluluğu olmadan ve anonim bir biçimde gerçekleşmektedir. Tom Sorell'e (2015) göre WikiLeaks ve Anonymous gibi organizasyonların bir yandan şeffaflık ve demokratik hesap verme zorunluluğundan bahsederken (democratic accountability), diğer yandan kendileriyle ilgili gizliliklerini sürdürmeleri güvenilirliklerine zarar vermektedir. Örneğin WikiLeaks eline geçen tüm verilerin doğruluğunu yayımlamadan önce kontrol ettiğini iddia etmektedir. Ancak bu kontrolleri gerçekleştirecek kaynaklara sahip olup olmadığı, veriler doğrulanırken kullanılan metotları veya kontrolleri gerçekleştirenlerin bu iş için yeterince donanımlı olup olmadığı kimse tarafından bilinmemektedir. Sorell'in 
(2015) dikkat çektiği bir diğer nokta ise WikiLeaks'in elde ettiği bazı bilgileri içeriden birilerinin sızdırmasıyla değil, Anonymous grubunun gerçekleştirdiği yasadışı siber saldırı aracılığıyla edinmiş olmasıdır.

\section{Sonuç}

Yeni BİT, toplumsal hareketlerin sahip olduğu imkân ve sınırlılıkları yeniden tanımlayarak önemli kaynaklar ve firsatlar sunmaktadır. Günümüz toplumsal hareketleri yeni BIT sayesinde, yıllardır geleneksel yollarla sürdürmekte oldukları birçok işlevi —halkı bilgilendirmek, eylem ve etkinliklerin koordinasyonu sağlamak ve yetkililer, destekçiler ve benzer vizyona sahip diğer STK'lar arasında iletişim sağlamak — artık daha hızlı, daha etkili, daha yaratıcı ve daha az maliyetli bir şekilde gerçekleştirebilmektedir. Buna ek olarak dünyanın çeşitli yerlerinde kendileriyle benzer düşünce, kimlik ve amaçlara sahip birey ve gruplarla birleşerek ulusötesi aktörler haline gelebilmektedir. Bütün bunlar yeni BİT'in toplumsal hareketler için, özellikle mobilizasyon yapıları ve örgütlenme süreci bakımından, önemli birer kaynak teşkil ettiği anlamına gelmektedir. Ayrıca, Internet tabanlı iletişim teknolojilerinin kolektif eylem grupları tarafindan birer alternatif medya kanalı olarak kullanılabiliyor oluşu, mücadelelerini kitlelere doğrudan iletebilmek, duygusal mobilizasyon sağlayabilmek ve destekçi ve katılımcı sayısını arttırabilmek açılarından bir söylemsel firsat yapısı oluşturmaktadır.

Sonuç olarak, yeni iletişim teknolojilerinin sağladığı firsat yapısı ve kaynakların ulusal ve ulusötesi toplumsal hareketler tarafindan mobilize edilmesinin, bu hareketlerin başarı şansı üzerinde hatırı sayılır bir etkiye sahip olduğu söylenebilir. Ancak bu, yeni BİT'in toplumsal hareketlerin başarısı için tek başına yeterli olmaya başladığı anlamına gelmemektedir. Zira yeni BíT kullanımının bir takım dezavantajları ve sınırlılıkları da beraberinde getirdiği ve geleneksel iletişim yolları ve sosyal ağların ise hâlâ önemini koruduğu görülmektedir. "Slacktivism", "hacktivism", yeni BİT üzerindeki hükümet kontrolü riski, geleneksel medyanın hâlâ önemli bir yere sahip oluşu, çevrimiçi ulusötesi topluluklardaki dil engeli ve kültürel farklılıklar, sanal toplulukların varlıklarını devam ettirebilmek için geleneksel topluluklara gereksinim duyuyor oluşu ve yüz yüze iletişimin katılım teşvik etme konusundaki etkisi gibi etkenlerin varlı̆̆ hareketlere katılımın artması ve hareketlerin devamlılığının sağlanması açısından çevrimdışı ve çevrimiçi iletişim kanallarının beraber kullanıldığı durumların ideal olduğuna işaret etmektedir. 


\section{Kaynakça}

Benford, Robert D. ve David A. Snow (2000), "Framing Processes and Social Movements: An Overview and Assessment", Annual Review of Sociology, 26: 611-639.

Bennett, W. Lance (2005), "Communicating Global Activism: Strengths and Vulnerabilities of Networked Politics", van de Donk, Win, Brian Loader, Paul Nixon ve Dieter Rucht (Der.), Cyberprotest: New Media, Citizens and Social Movements (London and New York: Routledge): 109-128.

Boykoff, Jules (2006), "Framing Dissent: Mass-Media Coverage of the Global Justice Movement", New Political Science, 28 (2): 201-228.

Brand, Karl-Werner (1990), "Cyclical Aspects of New Social Movements: Waves of Cultural Criticism and Mobilization Cycles of New Middle Class Radicals.", Dalton, Russell J. ve Manfred Kuechler (Der.). Challenging the Political Order: New Social Movements in Western Democracies (Cambridge: Polity Press): 23-42.

Brasted, Monica (2005), "Framing Protest: The Chicago Tribune and the New York Times during the 1968 Democratic Convention", Atlantic Journal of Communication, 13 (1): 1-25.

Breuer, Anita (2012), "The Role of Social Media in Mobilizing Political Protest: Evidence from the Tunisian Revolution", Discussion Paper, Deutsches Institut für Entwicklungspolitik, https://www.die-gdi.de/uploads/media/DP_10.2012.pdf (06.05.2017).

Cammaerts, Bart (2005), "ICT-Usage Among Transnational Social Movements in the Networked Society: To Organise, to Mobilise and to Debate", Silverstone, Roger (Der.), Media, Technology and Everyday Life in Europe: From Information to Communication (Aldershot, UK: Ashgate): 53-72.

Carty, Victoria (2015), Social Movements and New Technology (Boulder: Westview Press).

Castells, Manuel (1997), The Power of Identity: The Information Age: Economy, Society and Culture (2nd Ed.) (Oxford: Blackwell).

Castells, Manuel (2005), "The Network Society: from Knowledge to Policy", Castells, Manuel ve Gustavo Cardoso (Der.), The Network Society: From Knowledge to Policy (Washington: Johns Hopkins University): 3-21.

Castells, Manuel (2007), "Communication, Power and Counterpower in the Network Society", International Journal of Communication, 1: 238-266.

Chan, Joseph. M. ve Zhongdang Pan (2003), "Shifting Journalistic Paradigms: How China's Journalists Assess 'Media Exemplars', Communication Research, 30: 649-82.

Cohen, Jean (1999), "Strateji ya da Kimlik: Yeni Teorik Paradigmalar ve Sosyal Hareketler", Çayır, Kenan (Der.), Yeni Sosyal Hareketler: Teorik Açılımlar (İstanbul: Kaknüs Yayınları): 109129.

Cooper, Alice H. (2002), "Media Framing and Social Movement Mobilization: German Peace Protest Against INF Missiles, the Gulf War, and NATO Peace Enforcement in Bosnia", European Journal of Political Research, 41 (1): 37-80.

Çetinkaya, Y. Doğan (2008), "Tarih ve Kuram Arasında Toplumsal Hareketler", Çetinkaya, Y. Doğan (Der.), Toplumsal Hareketler: Tarih, Teori ve Deneyim (İstanbul: İletişim): 25-71.

Della Porta, Donatella ve Mario Diani (2006), Social Movements: An Introduction (Oxford: Blackwell Publishing).

Diani, Mario (1992), "The Concept of a Social Movement", The Sociological Review, 40 (1): 1-25.

Diani, Mario (2000), "Social Movement Networks Virtual and Real", Information, Communication \& Society, 3 (3): 386-401. 
Diani, Mario (2003), "Introduction: Social Movements, Contentious Actions, and Social Networks: 'From Metaphor to Substance'?". Diani, Mario ve Doug McAdam (Der.), Social Movements and Networks: Relational Approaches to Collective Action (New York: Oxford University Press): 1-19.

Edwards, Bob ve John D. McCarthy (2004), "Resources and Social Movement Mobilization", Snow, David A., Sarah A. Soule ve Hanspeter Kriesi (Der.), The Blackwell Companion to Social Movements (Oxford: Blackwell Publishing): 116-152.

Eltantawy, Nahed ve Julie B. Wiest (2011), "Social Media in the Egyptian Revolution: Reconsidering Resource Mobilization Theory" International Journal of Communication, 5: 1207-1224.

Gamson, William A. ve David S. Meyer (1996), "Framing Political Opportunity", McAdam, Doug, John McCarthy, and Mayer Zald (der.), Comparative Perspectives on Social Movements: Political Opportunities, Mobilizing Structures, and Cultural Framings (Cambridge: Cambridge University Press): 275-290.

Garrett, R. Kelly (2006), "Protest in an Information Society: A Review of Literature on Social Movements and New ICTs", Information, Communication and Society, 9 (2): 202-224.

Habermas, Jürgen (1981), "New Social Movements", Telos, 49: 33-37.

Harlow, Summer (2011), "Social Media and Social Movements: Facebook and an Online Guatemalan Justice Movement That Moved Offline", New Media \& Society, 14 (2): 225243.

Hertog, James K.,ve McLeod, Douglas M. (1995), "Anarchists wreak havoc in downtown Minneapolis: A multi-level study of media coverage of radical protest", Journalism \& Mass Communication Monographs, 151: 1-48.

Jenkins, J. Craig (1983), "Resource Mobilization Theory and the Study of Social Movements", Annual Review of Sociology, 9 (1): 527-553.

Koopmans, Ruud (1999), "Political. Opportunity. Structure. Some Splitting to Balance the Lumping", Sociological Forum, 14 (1): 93-105.

Koopmans, Ruud ve Susan Olzak (2002), Right-Wing Violence and the Public Sphere in Germany: The Dynamics of Discursive Opportunities, Unpublished manuscript, (Stanford University, Stanford).

Kriesi, Hanspeter (1996), "The Organisational Structure of New Social Movements in a Political Context", McAdam, Doug, John D. McCarthy, ve Mayer N. Zald (Der.), Comparative Perspectives on Social Movements: Political Opportunities, Mobilizing Structures, and Cultural Framings (Cambridge: Cambridge University Press): 152-184.

McAdam, Doug (1982), Political Process and the Development of Black Insurgency 1930-1970 (Chicago \& London: The University of Chicago Press).

McAdam, Doug (1996), "Conceptual Origins, Current Problems, Future Directions", McAdam, Doug, John D. McCarthy ve Mayer N. Zald (Der.), Comparative Perspectives on Social Movements: Political Opportunities, Mobilizing Structures, and Cultural Framings (Cambridge: Cambridge University Press): 23-40.

McAdam, Doug, Sidney Tarrow ve Charles Tilly (2001), Dynamics of Contention (Cambridge: Cambridge University Press).

McAdam, Doug, Sidney Tarrow ve Charles Tilly (2009), "Comparative Perspectives on Contentious Politics", Lichbach, Mark ve Alan Zuckerman (Der.), Comparative Politics: Rationality, Culture, and Structure: Advancing Theory in Comparative Politics (Cambridge: Cambridge University Press): 260-290.

McCarthy, John D. Ve Mayer N. Zald (1977), "Resource Mobilization and Social Movements: A 
Partial Theory", The American Journal of Sociology, 82 (6): 1212-1241.

McLeod, Douglas M. ve Benjamin H. Detenber (1999), "Framing Effects of Television News Coverage of Social Protest", Journal of Communication, 49: 3-23.

Melucci, Alberto (1980), "The New Social Movements: A Theoretical Approach", Social Science Information, 19 (2): 199-226.

Melucci, Alberto (1996), Challenging Codes: Collective Action in the Information Age (Cambridge: Cambridge University Press).

Melucci, Alberto (1999), "Çağdaş Hareketlerin Sembolik Meydan Okuması”, Çayır, Kenan (Der.), Yeni Sosyal Hareketler: Teorik Açılımlar içinde (İstanbul: Kaknüs Yayınları): 81-107.

Meyer, David. S. (2004), "Protest and Political Opportunities", Annual Review of Sociology, 30: 125145.

Mikhaylova, Galina (2014), “The 'Anonymous' Movement: Hacktivism as an Emerging Form of Political Participation”, Master's Thesis, Texas State University, San Marcos.

Morozov, Evgeny (2009), "From Slacktivism to Activism", Foreign Policy, http://foreignpolicy.com/ 2009/09/05/from-slacktivism-to-activism/ (08.05.2017).

Morris, Aldon D. ve Cedric Herring (1987), "Theory and Research in Social Movements: A Critical Review", Annual Review of Political Science, 2: 137-198.

Offe, Claus (1999), "Yeni Toplumsal Hareketler: Kurumsal Politikanın Sınırlarının Zorlanması", Çayır, Kenan (Der.), Yeni Sosyal Hareketler: Teorik Açılımlar içinde (İstanbul: Kaknüs Yayınları): 53-79.

Ogunsola, L. A. (2005), "Information and Communication Technologies and the Effects of Globalization: Twenty-First Century 'Digital Slavery' for Developing Countries - Myth or Reality?", Electronic Journal of Academic and Special Librarianship, 6 (1-2), http://southernlibrarianship.icaap.org/content/v06n01/ogunsola_101.htm (07.05.2017).

Parks, Malcolm R. (2011), "Social Network Sites as Virtual Communities", Papacharissi, Zizi (Der.), A Networked Self: Identity, Community, and Culture on Social Network Sites (New York \& London: Routledge): 105-123.

Passy, Florence (2003), "Social Networks Matter. But How?", Diani, Mario ve Doug McAdam (Der.), Social Movements and Networks: Relational Approaches to Collective Action (New York: Oxford University Press): 21-47.

Snow, David A., E. Burke Rochford, Jr., Steven K. Worden ve Robert D. Benford (1986), "Frame Alignment Processes, Micromobilization, and Movement Participation", American Sociological Review, 51 (4): 464-481.

Snow, David A., Louis A. Zurcher, Jr. ve Sheldon Ekland-Olson (1980), "Social Networks and Social Movements: A Microstructural Approach to Differential Recruitment", American Sociological Review, 45 (5): 787-801.

Sorell, Tom (2015), "Human Rights and Hacktivism: The Cases of Wikileaks and Anonymous", Journal of Human Rights Practice, 7 (3): 391-410.

Spier, Shaked (2011), "Collective Action2.0: The Impact of ICT-Based Social Media on Collective Action - Difference in Degree or Difference in Kind?", Bachelor's Thesis, HumboldtUniversität zu Berlin, Berlin.

Storck, Madeline (2011), "The Role of Social Media in Political Mobilisation: A Case Study of the January 2011 Egyptian Uprising", Master's Thesis, University of St Andrews, Scotland.

Tarrow, Sidney (1998), Power in Movement: Social Movements and Contentious Politics (Cambridge: Cambridge University Press). 
The Open University (2005), "ICTs in Everyday Life", http://www.open.edu/openlearn/ocw/ pluginfile.php/70381/mod_oucontent/oucontent_download/epub/557716887ab688054163 73fd5adbdd9e0cf572be/icts_in_everyday_life.epub (17.04.2017).

Tilly, Charles (1978), From Mobilization to Revolution (New York: McGraw-Hill).

Tilly, Charles (2008), Toplumsal Hareketler 1768-2004 (İstanbul: Babil Yayınları) (Çev. Orhan Düz).

Touraine, Alain (1985), "An Introduction to the Study of Social Movements", Social Research, 52 (4): 749-787.

Touraine, Alain (1988), Return of the Actor: Social Theory in Postindustrial Society (Minneapolis: University of Minnesota Press).

Tüfekçi, Zeynep (2014), "Social Movements and Governments in the Digital Age: Evaluating a Complex Landscape", Journal of International Affairs, 68 (1): 1-18.

Van Aelst, Peter ve Stefaan Walgrave (2004), "New Media, New Movements? The Role of the Internet in Shaping the 'Anti-Globalization' Movement", van de Donk, Win, Brian Loader, Paul Nixon ve Dieter Rucht (Der.), Cyberprotest: New Media, Citizens and Social Movements (London and New York: Routledge): 87-107.

Van Dijk, Jan (2006), The Network Society: Social Aspects of New Media, (2nd Ed.) (London: Sage Publications).

Vliegenthart, Rens ve Stefaan Walgrave (2012), "The Interdependency of Mass Media and Social Movements", Semetko, Holli ve Margaret Scammel (Der.), The Sage Handbook of Political Communication (London: Sage Publications): 387-398.

Webster, Frank (2006), Theories of the Information Society (3rd Ed.) (London \& New York: Routledge). 